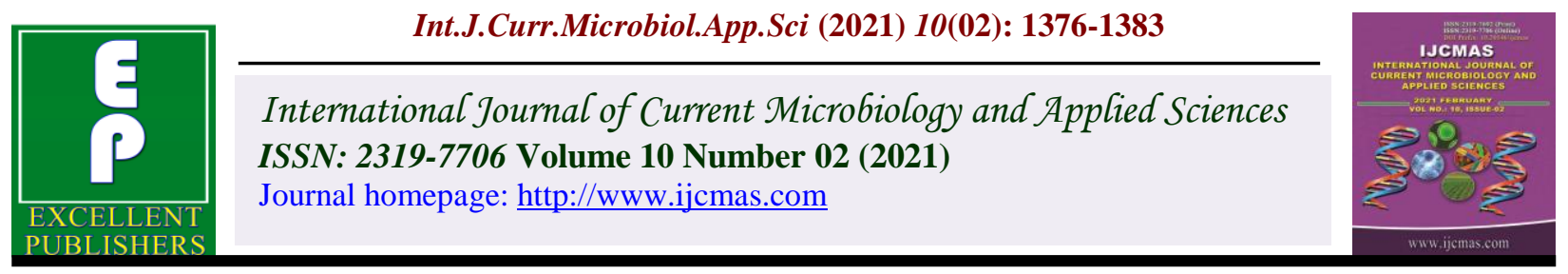

Original Research Article

https://doi.org/10.20546/ijcmas.2021.1002.164

\title{
Correlation and Path Analysis Studies for Yield and its Attributes in Tomato
}

\author{
Santosh Kumari* and B. S. Dogra \\ Department of Vegetable Science (College of Horticulture and Forestry, Neri, Hamirpur) \\ Dr Y S Parmar University of Horticulture and Forestry, Nauni, Solan, HP, HP, India \\ *Corresponding author
}

A B S T R A C T

\begin{tabular}{|l|}
\hline Key w or d s \\
$\begin{array}{l}\text { Correlation, Path } \\
\text { analysis, Fruit yield } \\
\text { and Tomato }\end{array}$ \\
\hline Article Info \\
\hline $\begin{array}{l}\text { Accepted: } \\
\text { 10 January } 2021 \\
\text { Available Online: } \\
\text { 10 February } 2021\end{array}$ \\
\hline
\end{tabular}

\section{Introduction}

Tomato is an important vegetable crop grown throughout the world. It is grown in tropical, subtropical and mild cold climatic regions of the world. Tomato is grown for its edible fruit, which is consumed either fresh or cooked and in the form of various processed products like juice, ketch up, sauce, puree, chutney, pickles and soup etc. Tomato being a nutritional crop, is considered as an important source of vitamin A, C and minerals like calcium, phosphorus and magnesium etc. In India, tomato is cultivated in different states like Uttar Pradesh, Karnataka, Himachal Pradesh, Maharashtra, Haryana, Punjab and
Bihar. In Himachal Pradesh, tomato is grown during summer and rainy seasons, as the climatic conditions are congenial for optimum plant growth and yield. Tomato is most remunerative cash crop of the low and mid hills of Himachal Pradesh. This vegetable has been under improvement through breeding for desired traits such as faster growth, uniform maturity with higher yields, early maturing varieties, biotic and abiotic stresses. Large number of genotypes should be studied to identify the promising ones. Correlation studies are of great significance as, if significant correlation values are established between yield and other economic traits, improvement could be made through selective 
plant breeding technique. Path analysis provides important information regarding direct and indirect effects of the characters contributing towards the yield of the plants.

\section{Materials and Methods}

The study was conducted at the experimental farm of the Department of Vegetable Science, UHF, Solan, Himachal Pradesh in Kharif, 2016. Experimental material comprised of thirty five genotypes. The seed sowing of all the genotypes was carried out in February, 2016 on the raised nursery beds. The experimental material was planted in a randomized complete block design with three replications in plot size of $1.8 \mathrm{~m} \times 1.8 \mathrm{~m}$. Twelve plants of each genotype were transplanted in each replication at spacing of $90 \mathrm{~cm} \times 30 \mathrm{~cm}^{\text {on }} 6^{\text {th }}$ April, 2016. Practices recommended in the Package of Practices of Vegetable Crops were followed for growing a healthy crop (Anonymous, 2013). The characters studied during the present study were days to $50 \%$ flowering, days to maturity, plant height, fruits per cluster, fruits per plant, fruit weight, fruit yield per plant and per hectare, fruit shape index, pericarp thickness, number of locules per fruit, total soluble solids, ascorbic acid, and harvest duration. Correlation studies were undertaken as per Al-Jibouri et al., (1958) and path analysis as per Dewey and Lu (1959).

\section{Results and Discussion}

Genotypic correlation coefficients among thirteen characters (Table 1) depicted that fruit yield per plant had positive and significant association with days to marketable maturity (0.430), plant height (0.215), number of fruits per cluster (0.200), average fruit weight (0.655), pericarp thickness (0.608) and harvest duration (0.360). However, it showed significant negative correlation with total soluble solids
(-0.441). Positive and significant association of fruit yield per plant with days to marketable maturity, average fruit weight, pericarp thickness and harvest duration has been reported by Khan and Samadia (2012) and Kingsley (2015). Positive and significant association of average fruit weight and pericarp thickness with fruit yield per plant was also observed by Mahapatra et al., (2013) and Kumar (2014). Prashant et al., (2008) noted positive and significant correlation of yield per plant with fruits per cluster and Joshi et al., (2004) with harvest duration. Significant and positive correlation of number of marketable fruits per plant, plant height, average fruit weight with marketable yield per plant has been reported by Sharma et al., (2019). Kumar et al., (2020) observed significant and positive association of average fruit weight and number of fruits per cluster with fruit yield per plant. Jogi et al., (2018) revealed significant and positive association of pericarp thickness and average fruit weight with fruit yield per plant. Significant and positive correlation of average fruit weight with yield per plant has been observed by Singh et al., (2018). Negative and significant association of total soluble solids with fruit yield per plant, was in accordance with the findings of Aysh et al., (2012) and Sharma et al., (2019).

Days to $50 \%$ flowering exhibited positive and significant association with number of locules per fruit (0.268) and harvest duration (0.256) and had negative and significant association with number of fruits per cluster (-0.757), number of fruits per plant (-0.667), fruit shape index (-0.242), total soluble solids (-0.199) and ascorbic acid (-0.217). Positive and significant association of days to $50 \%$ flowering with number of locules per fruit and harvest duration and negative and significant correlation with number of fruits per cluster was in accordance with Kumar (2014), whereas, negative and significant correlation 
of total soluble solids with days to $50 \%$ flowering was observed by Khan and Samadia (2012). Days to marketable maturity was positively and significantly correlated with average fruit weight (0.576), pericarp thickness (0.496) and ascorbic acid (0.240), while negatively and significantly with fruits per cluster (-0.225), fruits per plant $(-0.315)$ and total soluble solids (-0.594). Kumar (2014) also reported positive and significant correlation of days to marketable maturity with average fruit weight, pericarp thickness and ascorbic acid.

Plant height exhibited positive and significant association with number of fruits per plant (0.287), total soluble solids (0.234) and harvest duration (0.832), while negative and significant association with average fruit weight (-0.235) and ascorbic acid (-0.312). Kumar (2010), Rai (2015), Joshi et al., (2004) and Khan and Samadia (2012) also observed positive and significant association of plant height with harvest duration. Fruits per cluster had positive and significant association with fruits per plant (0.919) and fruit shape index (0.216) and had significant and negative association with fruit weight (-0.258), pericarp thickness $(-0.254)$ and locules per fruit (-0.286). Positive and significant association of fruits per cluster with fruits per plant was in accordance with Kumar (2014), Kumari and Sharma (2013), Rai (2015) and Kumar et al., (2020) and significant and negative correlation with fruit weight and locules per fruit was noted by Rai (2015).

Fruits per plant were positively and significantly correlated with total soluble solids (0.367) and negatively and significantly correlated with average fruit weight $(-0.450)$, pericarp thickness (-0.362) and locules per fruit (-0.282). Negative and significant association of fruits per plant with average fruit weight and pericarp thickness has been reported by Joshi et al., (2004), Manna and Paul (2012), Kumar (2014) and Rai (2015).
Average fruit weight showed positive and significant association with pericarp thickness (0.778), while negative and significant correlation with total soluble solids $(-0.734)$. Buckseth (2010), Rai (2015), Joshi et al., (2004) and Sharma et al., (2010) also proposed significant and positive association of average fruit weight with pericarp thickness. Singh et al., (2018) also observed significant and positive association of average fruit weight with pericarp thickness and significant and negative association with total soluble solids. Fruit shape index showed negative and significant correlation with number of locules per fruit (-0.262) and total soluble solids (-0.205) which was in accordance with the findings of Kumar (2014). Pericarp thickness exhibited negative and significant correlation with total soluble solids (-0.631). Ascorbic acid had negative and significant correlation with harvest duration (-0.242). The nature of phenotypic correlation was similar to genotypic correlation. But in some cases, the magnitude of phenotypic correlation was considerably lower and was statistically non significant while they were found significant at genotypic level.

Path coefficient analysis method was devised by Dewey and Lu (1959) which helps in partitioning the correlation coefficient under direct and indirect effects which permit a critical examination of the relative importance of each trait. In order to understand such effects of different independent characters or in combination with other characters on yield, the estimates of direct and indirect effects were computed through path coefficient analysis in the present investigation. Perusal of data from table 2 indicated that maximum positive direct effect towards fruit yield per plant was contributed by average fruit weight (0.877), followed by days to $50 \%$ flowering (0.619), number of fruits per cluster (0.611) and harvest duration (0.559). 
Table.1 Genotypic and Phenotypic coefficients of correlation among different traits in tomato

\begin{tabular}{|c|c|c|c|c|c|c|c|c|c|c|c|c|c|}
\hline Characters & & $\begin{array}{c}\text { Days to } \\
\text { marketable } \\
\text { maturity }\end{array}$ & $\begin{array}{c}\text { Plant } \\
\text { height } \\
(\mathrm{cm})\end{array}$ & $\begin{array}{c}\text { Numbers } \\
\text { of fruits } \\
\text { per cluster }\end{array}$ & $\begin{array}{c}\text { Numbers } \\
\text { of fruits } \\
\text { per plant }\end{array}$ & $\begin{array}{l}\text { Average } \\
\text { fruit } \\
\text { weight (g) }\end{array}$ & $\begin{array}{l}\text { Fruit } \\
\text { Shape } \\
\text { Index }\end{array}$ & $\begin{array}{c}\text { Pericarp } \\
\text { thickness } \\
(\mathbf{m m})\end{array}$ & $\begin{array}{c}\text { Number } \\
\text { of locules } \\
\text { per fruit }\end{array}$ & $\begin{array}{c}\text { Total } \\
\text { soluble } \\
\text { solids }\left({ }^{0} \mathbf{B}\right)\end{array}$ & $\begin{array}{c}\text { Ascorbic } \\
\text { acid } \\
(\mathbf{m g} / 100 \mathrm{~g})\end{array}$ & $\begin{array}{l}\text { Harvest } \\
\text { duration }\end{array}$ & $\begin{array}{c}\text { Fruit } \\
\text { yield/plant } \\
(\mathbf{k g})\end{array}$ \\
\hline \multirow{2}{*}{$\begin{array}{l}\text { Days to } 50 \% \\
\text { erings }\end{array}$} & G & -0.043 & 0.191 & $-0.757^{* *}$ & $-0.667^{* *}$ & 0.077 & $-0.242^{*}$ & 0.017 & $0.268^{* * *}$ & $-0.199^{*}$ & $-0.217^{*}$ & $0.256^{* *}$ & -0.141 \\
\hline & $\mathbf{P}$ & 0.126 & $0.214^{*}$ & $-0.670^{* *}$ & $-0.586^{* * *}$ & 0.100 & -0.114 & 0.063 & $0.302^{* *}$ & -0.132 & -0.155 & $0.303^{* *}$ & -0.103 \\
\hline \multirow{2}{*}{$\begin{array}{l}\text { Days to } \\
\text { ketable maturity }\end{array}$} & G & & -0.169 & $-0.225^{*}$ & $-0.315^{* *}$ & $0.576^{* *}$ & 0.029 & $0.496^{* *}$ & -0.071 & $-0.594^{* *}$ & $0.240^{*}$ & -0.094 & $0.430^{* *}$ \\
\hline & $\mathbf{P}$ & & -0.113 & -0.179 & $-0.258^{* *}$ & $0.554^{* *}$ & 0.131 & $0.498^{* *}$ & -0.004 & $-0.485^{* *}$ & $0.263^{* *}$ & -0.010 & $0.418^{* *}$ \\
\hline \multirow{2}{*}{ Plant height } & G & & & 0.057 & $0.287^{* *}$ & $-0.235^{*}$ & -0.053 & -0.131 & -0.057 & $0.234^{*}$ & $-0.312^{* * *}$ & $0.832^{* *}$ & $0.215^{*}$ \\
\hline & $\mathbf{P}$ & & & 0.063 & $0.291^{* *}$ & $-0.226^{*}$ & -0.025 & -0.118 & -0.042 & $0.243^{*}$ & $-0.297^{* *}$ & $0.832^{* *}$ & $0.220^{*}$ \\
\hline \multirow{2}{*}{$\begin{array}{l}\text { Numbers of } \\
\text { ts per cluster }\end{array}$} & G & & & & $0.919^{* *}$ & $-0.258^{* *}$ & $0.216^{*}$ & $-0.254^{* *}$ & $-0.286^{* *}$ & 0.165 & 0.025 & -0.136 & $0.200^{*}$ \\
\hline & $\mathbf{P}$ & & & & $0.919^{* * *}$ & $-0.252^{* * *}$ & $0.225^{*}$ & $-0.245^{*}$ & $-0.273^{* *}$ & 0.172 & 0.032 & -0.122 & $0.203^{*}$ \\
\hline \multirow{2}{*}{$\begin{array}{l}\text { Numbers of } \\
\text { ts per plant }\end{array}$} & G & & & & & $-0.450^{* * *}$ & 0.127 & $-0.362^{* *}$ & $-0.282^{* *}$ & $0.367^{* *}$ & -0.039 & 0.097 & 0.154 \\
\hline & $\mathbf{P}$ & & & & & $-0.443^{* *}$ & 0.140 & $-0.351^{* *}$ & $-0.268^{* *}$ & $0.372^{* *}$ & -0.031 & 0.107 & 0.157 \\
\hline \multirow{2}{*}{$\begin{array}{l}\text { Average fruit } \\
\text { bht (g) }\end{array}$} & G & & & & & & 0.001 & $0.778^{* *}$ & 0.128 & $-0.734^{* *}$ & 0.134 & -0.088 & $0.655^{* *}$ \\
\hline & $\mathbf{P}$ & & & & & & 0.020 & $0.779^{* *}$ & 0.137 & $-0.717^{* *}$ & 0.141 & -0.073 & $0.657^{* * *}$ \\
\hline \multirow{2}{*}{$\begin{array}{l}\text { Fruit shape } \\
x\end{array}$} & G & & & & & & & 0.140 & $-0.262^{* *}$ & $-0.205^{*}$ & 0.134 & -0.057 & 0.071 \\
\hline & $\mathbf{P}$ & & & & & & & 0.165 & $-0.213^{*}$ & -0.164 & 0.157 & -0.008 & 0.085 \\
\hline \multirow{2}{*}{$\begin{array}{l}\text { Pericarp } \\
\text { kness (mm) }\end{array}$} & G & & & & & & & & 0.092 & $-0.631^{* * *}$ & 0.167 & 0.070 & $0.608^{* *}$ \\
\hline & $\mathbf{P}$ & & & & & & & & 0.109 & $-0.606^{* * *}$ & 0.178 & 0.090 & $0.610^{* *}$ \\
\hline \multirow{2}{*}{$\begin{array}{l}\text { Number of } \\
\text { les per fruit }\end{array}$} & G & & & & & & & & & -0.114 & 0.057 & -0.076 & -0.132 \\
\hline & $\mathbf{P}$ & & & & & & & & & -0.093 & 0.073 & -0.047 & -0.120 \\
\hline \multirow{2}{*}{$\begin{array}{l}\text { Total soluble } \\
\text { Is }\left({ }^{0} \mathrm{~B}\right)\end{array}$} & G & & & & & & & & & & $-0.243^{*}$ & 0.129 & $-0.441^{* *}$ \\
\hline & $\mathbf{P}$ & & & & & & & & & & $-0.226^{*}$ & 0.149 & $-0.429^{* *}$ \\
\hline \multirow{2}{*}{$\begin{array}{l}\text { Ascorbic acid } \\
\text { /100 g) }\end{array}$} & G & & & & & & & & & & & $-0.242^{*}$ & 0.031 \\
\hline & $\mathbf{P}$ & & & & & & & & & & & $-0.217^{*}$ & 0.038 \\
\hline \multirow{2}{*}{$\begin{array}{l}\text { Harvest } \\
\text { duration (days) }\end{array}$} & G & & & & & & & & & & & & $0.360^{* *}$ \\
\hline & $\mathbf{P}$ & & & & & & & & & & & & $0.365^{* *}$ \\
\hline
\end{tabular}

*Significant at $5 \%$ level of significance

**Significant at $1 \%$ level of significance 
Table.2 Estimates of direct and indirect effects of different traits on yield in tomato

\begin{tabular}{|c|c|c|c|c|c|c|c|c|c|c|c|c|c|}
\hline Characters & $\begin{array}{c}\text { Days to } \\
50 \% \\
\text { flowerings }\end{array}$ & \begin{tabular}{|c} 
Days \\
to \\
marketable \\
maturity
\end{tabular} & $\begin{array}{l}\text { Plant } \\
\text { height } \\
\text { (cm) }\end{array}$ & $\begin{array}{c}\text { Numbers } \\
\text { of } \\
\text { fruits } \\
\text { per cluster }\end{array}$ & $\begin{array}{l}\text { Numbers } \\
\text { of fruits } \\
\text { per plant }\end{array}$ & $\begin{array}{l}\text { Average } \\
\text { fruit } \\
\text { weight (g) }\end{array}$ & $\begin{array}{l}\text { Fruit } \\
\text { Shape } \\
\text { index }\end{array}$ & $\begin{array}{l}\text { Pericarp } \\
\text { thickness } \\
(\mathbf{m m})\end{array}$ & $\begin{array}{c}\text { Number } \\
\text { of } \\
\text { locules } \\
\text { per fruit }\end{array}$ & $\begin{array}{c}\text { Total } \\
\text { soluble } \\
\text { solids } \\
\left({ }^{0} \mathbf{B}\right)\end{array}$ & $\begin{array}{l}\text { Ascorbic } \\
\text { acid } \\
(\mathrm{mg} / 100 \\
\text { g) }\end{array}$ & $\begin{array}{c}\text { Harvest } \\
\text { duration } \\
\text { (days) }\end{array}$ & $\begin{array}{c}\text { GCCFY } \\
\text { PP }\end{array}$ \\
\hline Days to $50 \%$ flowerings & 0.619 & -0.015 & -0.061 & -0.462 & -0.308 & 0.067 & -0.020 & 0.004 & -0.001 & -0.091 & -0.012 & 0.143 & -0.141 \\
\hline $\begin{array}{l}\text { Days to marketable } \\
\text { maturity }\end{array}$ & -0.026 & 0.370 & 0.054 & -0.137 & -0.145 & 0.505 & 0.002 & 0.120 & 0.0004 & -0.274 & 0.013 & -0.052 & 0.430 \\
\hline Plant height (cm) & 0.118 & -0.062 & -0.320 & 0.034 & 0.132 & -0.206 & -0.004 & -0.031 & 0.0003 & 0.107 & -0.018 & 0.465 & 0.215 \\
\hline $\begin{array}{l}\text { Numbers of fruits per } \\
\text { cluster }\end{array}$ & -0.468 & -0.083 & -0.018 & 0.611 & 0.424 & -0.226 & 0.018 & -0.061 & 0.001 & 0.076 & 0.001 & -0.075 & 0.200 \\
\hline $\begin{array}{l}\text { Numbers of fruits per } \\
\text { plant }\end{array}$ & -0.413 & -0.116 & -0.091 & 0.561 & 0.462 & -0.395 & 0.010 & -0.087 & 0.001 & 0.169 & -0.002 & 0.054 & 0.154 \\
\hline Average fruit weight (g) & 0.047 & 0.213 & 0.075 & -0.157 & -0.208 & 0.877 & 0.0001 & 0.188 & -0.0008 & -0.339 & 0.007 & -0.049 & 0.655 \\
\hline Fruit shape index & -0.149 & 0.010 & 0.016 & 0.132 & 0.058 & 0.001 & 0.083 & 0.034 & 0.001 & -0.094 & 0.007 & -0.031 & 0.071 \\
\hline Pericarp thickness (mm) & 0.010 & 0.183 & 0.042 & -0.155 & -0.167 & 0.682 & 0.011 & 0.242 & -0.0006 & -0.291 & 0.009 & 0.039 & 0.608 \\
\hline $\begin{array}{l}\text { Number of locules per } \\
\text { fruit }\end{array}$ & 0.166 & -0.026 & 0.018 & -0.174 & -0.130 & 0.112 & -0.022 & 0.022 & -0.006 & -0.052 & 0.003 & -0.042 & -0.132 \\
\hline Total soluble solids $\left({ }^{0} \mathrm{~B}\right)$ & -0.123 & -0.220 & -0.075 & 0.100 & 0.169 & -0.644 & -0.017 & -0.152 & 0.0007 & 0.461 & -0.014 & 0.072 & -0.441 \\
\hline Ascorbic acid (mg/100 g) & -0.134 & 0.089 & 0.100 & 0.015 & -0.018 & 0.118 & 0.011 & 0.040 & -0.0004 & -0.112 & 0.057 & -0.135 & 0.031 \\
\hline Harvest duration (days) & 0.158 & -0.034 & -0.266 & -0.082 & 0.045 & -0.077 & -0.004 & 0.017 & 0.0004 & 0.059 & -0.013 & 0.559 & 0.360 \\
\hline
\end{tabular}

At genotypic level, the residual effect was recorded to be 0.07 
The other characters which showed positive direct effect were number of fruits per plant (0.462), total soluble solids $(0.461)$, days to marketable maturity (0.370), pericarp thickness (0.242), fruit shape index (0.083) and ascorbic acid (0.057). Plant height (0.320 ) and number of locules per fruit (0.006 ) had negative direct effect on fruit yield per plant. Days to marketable maturity $(0.213)$ and pericarp thickness (0.188) recorded maximum positive indirect effect via average fruit weight on fruit yield. Harvest duration (0.143) exerted maximum positive indirect effect via days to $50 \%$ flowering. Number of fruits per plant (0.424) exerted maximum positive indirect effect via number of fruits per cluster and days to $50 \%$ flowering (0.158) recorded maximum positive indirect effect via harvest duration. At genotypic level, the residual effect was recorded to be 0.07. Golani et al., (2007), Ramana et al., (2007), Tiwari and Uphadhyay (2011), Sharma and Singh (2012), Kumar et al., (2013), Srivastava et al., (2013), Meena \& Bahadur (2015) and Prajapati et al., (2015) reported highest positive direct effect of average fruit weight on fruit yield per plant. Srivastava et al., (2013) and Meena and Bahadur (2015) noted positive direct effect of days to $50 \%$ flowering. Harer et al., (2002) and Kumar et al., (2003) also observed high positive direct effect of average fruit weight and fruits per cluster on yield per plant. Sharma et. al. (2019) observed positive direct effect of fruit weight, fruit shape index, number of locules and days to $50 \%$ flowering. Singh et al., (2020) observed positive direct effect of number of fruits per cluster and pericarp thickness. Ara et al., (2009) proposed positive direct effect of harvest duration. Kumar (2010), Manna and Paul (2012), Kumar et al., (2013), Reddy et al., (2013), Khapte and Jansirani (2014), Premalakshmi et al., (2014) and Menna and Bahadur (2015) also noted positive direct effect of number of fruits per plant. Harer et al., (2002), Makesh et al., (2006) and Ramana et al., (2007) observed positive direct effect of total soluble solids. Positive direct effect of days to marketable maturity was noted by Prajapati et al., (2015). Positive direct effect of pericarp thickness has been proposed by Manna and Paul (2012) and Kumar (2014). Ara et al., (2009) and Saleem et al., (2013) reported negative and direct effect of number of locules per fruit. Jogi et al., (2018) and Singh et al., (2018) revealed positive direct effect of number of fruits per plant and average fruit weight.

\section{References}

Al-Jibouri, A., Miller, P. A. and Robison, H. F. 1958. Genotypic and environmental variation and covariation in upland cotton crops of inter-specific origin. Agronomy Journal. 50: 626-636.

Ara Anjum, Narayan Raja, Ahmed Nazeer and Khan, S. H. 2009. Genetic variability and selection parameters for yield and quality attributes in tomato. Indian Journal of Horticulture. 66(1): 73-78.

Aysh, F. A., Kutma, H., Serhan, M., Zoubai, A. A. and Naseer, M. A. 2012. Genetic analysis and correlation studies of yield and fruit quality traits in tomato (Solanum lycopersicum L.). New York Science Journal. 5: 142-45.

Buckseth, T. 2010. Studies on genetic divergence in tomato (Solanum lycopersicum L.), M.Sc. Thesis, Department of Vegetable Science. Dr. Y. S. Parmar University of Horticulture and Forestry, Nauni, Solan.

Dewey, D. and Lu, K. H. 1959. A correlation and path coefficient analysis in crested wheat grass seed production. Journal of Agronomy. 54: 515-518.

Golani, I. J., Mehta, D. R., Purohit, V. L., Pandya, H. M. and Kanzariya, M.V. 2007. Genetic variability, correlation 
and path coefficient studies in tomato. Indian Journal of Agricultural Research. 41:146- 49 .

Harer, P. N., Lad, D. B. and Bhor, T. J. 2002. Correlation and path analysis studies in tomato. Journal of Maharashtra Agricultural Universities. 27:302-03.

Jogi Mahantesh, Lingaiah, Indiresh, K. M, Singh, T. H, Samuel, D. K. and Ramachandra, R. K. 2018. Studies on correlation and path coefficient analysis in tomato (Solanum lycopersicum L.). International Journal of Chemical Studies. 6(5): 1499-1502.

Joshi Arun, Vikram Amit and Thakur, M. C. 2004. Studies on genetic variability, correlation and path analysis for yield and physio-chemical traits in tomato (Lycopersicon esculentum Mill.). Progressive Horticulture. 36:51-58.

Khan, H. and Samadia, D. K. 2012. Variability and association studies in tomato germplasm under hightemperature arid region. Journal of Horticultural Sciences. 7: 194-98.

Khapte, P. S. and Jansirani, P. 2014. Genetic variability and performance studies of tomato (Solanum lycopersicum L.) genotypes for fruit quality and yield. Trends in Biosciences 7:1246-48.

Kingsley, O. 2015. Studies on genetic variability in agronomic and fruit quality traits among some tomato (Solanum lycopersicum L.) genotypes, M.Sc. Thesis, University of Ghana, Ghana

Kumar Dharminder, Kumar Rajeev, Kumar Sandeep, Bhardwaj, M. L., Thakur, M.C., Kumar Ramesh, Thakur, K. S., Dogra, B. S., Vikram Amit, Thakur Ashok and Kumar P. 2013. Genetic variability, correlation and path coefficient analysis in tomato. International Journal of Vegetable Science. 19: 313-23.

Kumar Kiran, Sharma Dhananjay, Singh
Jitendra and Thakur Padmakshi 2020.Correlation and path coefficient analysis in tomato (Solanum lycopersicum L.). International Journal of Current Microbiology and Applied Sciences. 9(6): 1944-1950.

Kumar, N. 2014. Studies on genetic variability in tomato (Solanum lycopersicum L.) genotypes for different horticultural traits, M.Sc. Thesis, Department of Vegetable Science, Dr. Y. S. Parmar University of Horticulture and Forestry, Nauni, Solan.

Kumar, S. 2010. Genetic variability and interrelationship of traits in $\mathrm{F}_{3}$ progenies of tomato (Lycopersicon esculentum Mill.) under cold desert of Leh-Ladakh. Crop Improvement. 37:66-72.

Kumar, V. R. A., Thakur, M. C. and Hedau, N. K. 2003. Correlation and path coefficient analysis in tomato (Lycopersicon esculentum Mill.). Annals of Agricultural Research. 24:175-77.

Kumari Santosh and Sharma, M. K. 2013. Genetic variability studies in tomato (Solanum lycopersicum L.) Vegetable Science. 40:83-86.

Mahapatra, A. S., Singh, A. K., Vani, V. M., Mishra, R., Kumar, H. and Rajkumar, B. V. 2013. Inter-relationship for various components and path coefficient analysis in tomato (Lycopersicon esculentum Mill.). International Journal of Current Microbiology and Applied Sciences. 2: 147-152.

Makesh, S., Ramaswamy, N. and Puddan, M. 2006. Character association and path coefficient analysis in tomato (Lycopersicon esculentum Mill.). Research on crops. 7:496-99.

Manna Madhurina and Paul Amitava. 2012. Studies on genetic variability and characters association of fruit quality parameters in tomato. HortFlora Research Spectrum. 1: 110-16. 
Prajapati, S., Tiwari, A., Kadwey, S., Sharma, S. K. and Raghuwanshi, O. 2015. Correlation and path coefficient analysis of fruits yield and its attributing traits in tomato (Lycopersicon esculentum Mill.). Indian Research Journal of Genetics \& Biotechnology. 7:138-47.

Prashanth, S. J., Jaiprakashnarayan, R. P., Mulge, R. and Madalageri, M. B. 2008. Correlation and path analysis in tomato (Lycopersicon esculentum Mill.). The Asian Journal of Horticulture. 3:403-08.

Premalakshmi, V., Kumar, S. R. and T. Arumugam. 2014. Evaluation and genetic studies in tomato genotypes. Trends in Biosciences. 7: 1407-10.

Rai, A. K. 2015. Genetic divergence studies in tomato (Solanum lycopersicum L.), M.Sc. thesis, Department of Vegetable Science, Dr. Dr Y. S. Parmar University of Horticulture and Forestry, Nauni, Solan, HP, India. pp 50-72

Ramana, C. V., Shankar, V. G., Kumar, S. S. and Rao, P. V. 2007. Trait interrelationship studies in tomato (Lycopersicon esculentum Mill.). Research on crops. 8:213-18.

Reddy, B. R., Begum, H., Sunil, N. and Reddy, T. M. 2013. Genetic divergence studies in exotic collections of tomato (Solanum lycopersicum L.). International Journal of Agricultural Sciences. 9(2): 588-92.

Saleem, M. Y., Iqbal, Q. and Asghar, M. 2013. Genetic variability, heritability, character association and path analysis in $F_{1}$ hybrids of tomato. Pakistan Journal of Agriculture Science 50: 649-
53

Sharma, B. and Singh, J. P. 2012. Correlation and path coefficient analysis for quantitative and qualitative traits for fruit yield and seed yield in tomato genotypes. Indian Journal of Horticulture. 69:540-44.

Sharma, J., Singh, K. A. and Tiwari, S. P. 2010. Selection parameters for productive plant type in tomato (Lycopersicon esculentum Mill.). Journal of Hill Agriculture. 1:52-55.

Sharma Parveen, Dhillon Navjot Singh, Kumar Vineet and Kumar Pardeep. 2019. Correlation and path analysis for yield and its contributing traits in tomato (Solanum lycopersicum L.) under the protected environment. Journal of Pharmacnosy and Phytochemistry, SPI: 447-450.

Singh, Ashish K., Solankey, S. S., Akhtar Shirin, Kumari Preeti and Chaurasiya Jagdeep. 2018. Correlation and path coefficient analysis in tomato (Solanum lycopersicum L.). International Journal of Current Microbiology and Applied Sciences. Special Issue-7: 4278-4285.

Srivastava, K., Kumari, K., Singh, S. P. and Kumar, R. 2013. Association studies for yield and its component traits in tomato (Solanum lycopersicum L.). Plant Archives 13:105-12.

Tiwari, J. K. and Upadyaay, D. 2011. Correlation and path-coefficient studies in tomato (Lycopersicon esculentum Mill.). Research Journal of Agricultural Sciences. 2:63-68.

\section{How to cite this article:}

Santosh Kumari and Dogra, B. S. 2021. Correlation and Path Analysis Studies for Yield and its Attributes in Tomato. Int.J.Curr.Microbiol.App.Sci. 10(02): 1376-1383. doi: https://doi.org/10.20546/ijcmas.2021.1002.164 